\title{
Mercury in Pelecanus occidentalis of the Cispata bay, Colombia
}

\author{
Mercurio en Pelecanus occidentalis de la bahía de Cispatá, \\ Colombia
}

\author{
Saudith Burgos $\mathrm{N}^{1 *}$ Quim, José Marrugo N, ${ }^{1} \mathrm{Ph} . \mathrm{D}$, Amado Navarro $\mathrm{F}^{2} \mathrm{Ph} . \mathrm{D}$, \\ Ivan Urango $\mathrm{C}^{1}{ }^{1}$ Quim.
}

\begin{abstract}
${ }^{1}$ Universidad de Cordoba, Faculty of Basic Sciences and Engineering, Research Group of Waters, Applied Chemistry and the Environment. Carrera 6 No. 76-103. Monteria - Colombia. ${ }^{2}$ Universidad Tecnologica de Izucar de Matamoros. Extension to Reform 168, Barrio de Santiago Mihuacan, Izucar de Matamoros, Puebla, Mexico.*Correspondence: saubur1224@hotmail.com.
\end{abstract}

Received: September 2012; Accepted: October 2013.

\begin{abstract}
Objective. Assessment the total concentration of mercury in the liver and feathers of Pelecanus occidentalis of the Cispata bay, Colombia. Materials and methods. Mercury concentrations in liver and feather of Pelecanus occidentalis residents in the Cispata bay - Colombia were evaluated by digestion with an acidic mixture of $\mathrm{H}_{2} \mathrm{SO}_{4}-\mathrm{HNO}_{3}$ and $\mathrm{KMnO}_{4}$ to eliminate organic matter. The concentration of mercury was determined by the Atomic Absorption - Cold Vapor method (CVAAS). Results. Total mercury levels found in this study were higher in feathers $(0.31-9.17 \mathrm{mgHg} / \mathrm{kg})$ than in the liver $(0.63-6.29 \mathrm{mgHg} / \mathrm{kg})$, being higher than those reported in other seabirds studies. Conclusions. The high levels of total mercury in feathers and liver can be explained by the feeding habits of the organisms under study, showing the utility of feathers as a potential non-invasive tool for the monitoring of the ecosystem and thereby preventing the sacrifice of specimens.
\end{abstract}

Key words: Aquatic ecosystem, chemical analysis, marine pollution (Source: UNESCO).

\section{RESUMEN}

Objetivo. Evaluar las concentraciones de mercurio total en hígado y plumas de Pelecanus occidentalis de la Bahía de Cispatá, Colombia. Materiales y métodos. Se evaluó la concentración de mercurio en hígado y plumas de Pelecanus occidentalis pertenecientes a la bahía de Cispatá - Colombia, por digestión con una mezcla ácida de $\mathrm{H}_{2} \mathrm{SO}_{4}-\mathrm{HNO}_{3}$ y $\mathrm{KMnO}_{4}$ para eliminar la materia orgánica. La concentración de mercurio fue determinada por el método de Absorción Atómica - Vapor Frio (CVAAS). Resultados. Los valores de mercurio total fueron más altos en plumas $(0.31-9.17 \mathrm{mgHg} / \mathrm{kg})$ que en hígado $(0.63-6.29 \mathrm{mgHg} / \mathrm{kg}$ ), siendo mayores a los reportados en otros estudios de aves marinas. Conclusiones. Las altas concentraciones de mercurio total en plumas e hígado pueden ser atribuidas a la dieta de los organismos estudiados; demostrando la utilidad de las plumas como herramienta potencial no invasiva de monitoreo del ecosistema y evitando con ello el sacrificio de los individuos.

Palabras clave: Análisis químico, contaminación marina, ecosistema acuático (Fuente: UNESCO). 


\section{INTRODUCTION}

Seabirds are often utilized as indicators of the health of marine ecosystems and are frequently used to monitor mercury $(\mathrm{Hg})$ concentrations in marine environments (1). Birds are an excellent bioindicator of metal contamination and can be used as effective and accurate monitors of metals for different reasons: (i) the birds are plentiful in number, (ii) have a wide range of geographical distribution, (iii) have different feeding habits and occupy different trophic levels, and (iv) many birds have a high longevity (2).

The use of chemicals is increasing daily in the industry, pharmacy and at home. Aquatic environments are particularly vulnerable due to the rapid movement of contaminants in the water when compared to movement in terrestrial environments. The concentrations of many of these toxic substances are high in marine and coastal ecosystems due to the influence of rivers, runoff water, point sources of pollution, transport and atmospheric deposition $(3,4)$.

The effects of pollutants on seabirds as on other organisms are the result of acute or chronic exposure. Acute exposure to a contaminant may have a different impact than the chronic ingestion of small amounts. For seabirds, the ingestion of food and water are the main routes of exposure (3).

Seabirds eliminate through the feather molt and a small proportion of the body burden is excreted in the manure or eggs. High mercury concentrations in birds affect the immune, detoxification and nervous systems. This article assesses the mercury concentrations in feathers and liver of Pelecanus occidentalis (pelican) collected in the Cispata bay, Colombia, which is an important biodiversity location. Currently no study has been documented on mercury pollution on aquatic birds of the bay of Cispata - Colombia.

\section{MATERIALS AND METHODS}

Study area. The Cispata bay is located in the Colombian Caribbean coast, former delta of the river Sinu on the southwestern tip of the Gulf of Morrosquillo, which is part of the municipalities of San Antero and San Bernardo del Viento, Department of Cordoba (Figure 1). The geographical coordinates of the endpoints of the study area are: north latitude $9^{\circ} 25^{\prime} 12^{\prime \prime}$ and $9^{\circ} 20^{\prime} 8^{\prime \prime}$ and west longitude $75^{\circ} 47^{\prime} 37^{\prime \prime}$ and $75^{\circ} 55^{\prime} 30^{\prime \prime}(5)$.

\section{INTRODUCCIÓN}

Las aves marinas a menudo son utilizadas como indicadoras de la salud de los ecosistemas marinos y frecuentemente usadas para monitorear las concentraciones de mercurio $(\mathrm{Hg})$ en ambientes marinos (1). Las aves son un excelente bioindicador de la contaminación metálica y pueden ser usados como monitores efectivos y precisos de metales por diferentes razones: (i) las aves son abundantes en número, (ii) tienen un gran rango de distribución geográfica, (iii) presentan variados hábitos alimenticios y ocupan diferentes niveles tróficos, y (iv) muchas aves tienen alta longevidad (2).

El uso de químicos se está incrementando diariamente en la industria, farmacia y en el hogar. Los ambientes acuáticos son particularmente vulnerables debido al rápido movimiento de los contaminantes en el agua, comparado con el movimiento en ambientes terrestres. Las concentraciones de muchos de estos tóxicos son elevadas en ecosistemas marinos y costeros debido a la influencia de los ríos, escorrentías, fuentes puntuales de contaminación, transporte y deposición atmosférica $(3,4)$.

Los efectos de los contaminantes sobre las aves marinas, como en otros organismos, son el resultado de la exposición que puede ser aguda o crónica. La exposición aguda a un contaminante puede tener un impacto diferente a la ingesta crónica de pequeñas cantidades. Para las aves marinas, la ingestión de alimentos y agua son las principales rutas de exposición (3).

Las aves marinas eliminan mercurio a través de la muda y una pequeña proporción de la carga corporal es excretada en el guano o huevos. Las altas concentraciones de mercurio en aves afectan los sistemas inmune, de detoxificación y el nervioso. En este artículo se evalúan las concentraciones de mercurio en plumas e hígado de Pelecanus occidentalis (pelicano) colectados en la bahía de Cispatá, Colombia, el cual es un importante sitio de biodiversidad. Actualmente no se encuentra documentado algún estudio acerca de la contaminación por mercurio en aves acuáticas de la bahía de Cispatá - Colombia.

\section{MATERIALES Y MÉTODOS}

Área de estudio. La bahía de Cispatá, se encuentra localizada en el Litoral Caribe colombiano, antiguo delta del río Sinú, en el extremo suroeste del Golfo de Morrosquillo, haciendo parte de los municipios de San Antero y San Bernardo del Viento, departamento de Córdoba (Figura 1). Las coordenadas geográficas de los puntos extremos del área objeto del estudio son: latitud norte $9^{\circ} 25^{\prime} 12^{\prime \prime}$ y $9^{\circ} 20^{\prime} 8^{\prime \prime}$ y longitud oeste $75^{\circ} 47^{\prime} 37^{\prime \prime}$ y $75^{\circ} 55^{\prime} 30^{\prime \prime}$ (5). 


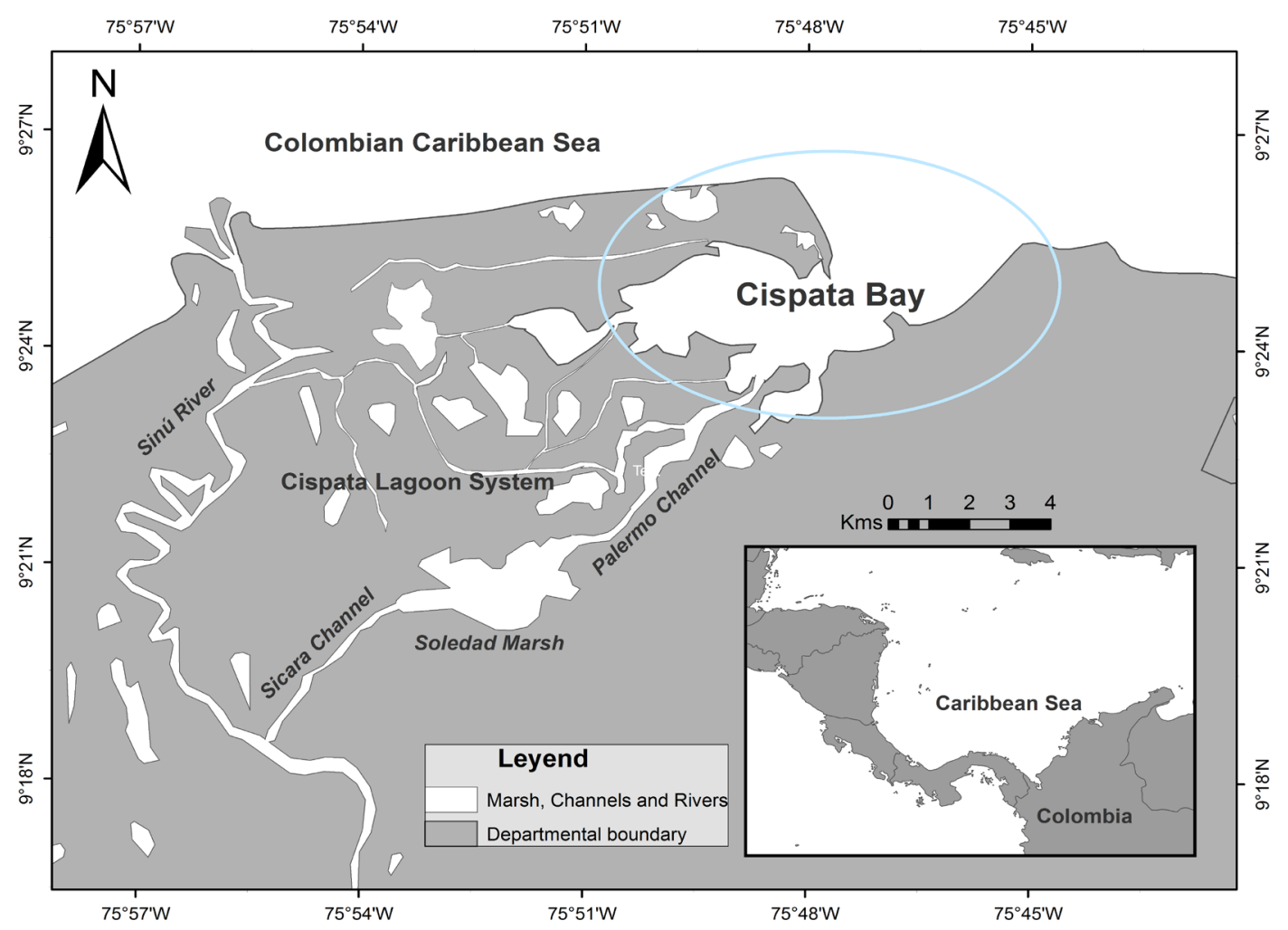

Figure 1. Study area: Cispata Bay - Colombia

Sample collection. Pelecanus occidentalis were captured $(n=10)$ during March 2010 and July 2011 in the Cispata bay, which included 6 young and 4 adult specimens, according to their morphometric variables such as weight, wingspan and beak length. The birds were euthanized and transported immediately to the laboratory for their dissection in order to separate the feathers and liver, which were tagged and packed in polythene bags. The latter were refrigerated until analysis. Permission for the capture and processing of birds was authorized by the local environmental authority (Corporación Autónoma Regional de los Valles del Sinú y del San Jorge, CVS).

Chemical analysis. Feather samples were washed with deionized water and acetone for eliminating free metals, they were then dried at $60^{\circ} \mathrm{C}$ for $48 \mathrm{~h}$ and the liver and feather samples were digested with a mixture of $\mathrm{H}_{2} \mathrm{SO}_{4}-\mathrm{HNO}_{3}(2: 1$, $\mathrm{v} / \mathrm{v}$ ) at $100-110^{\circ} \mathrm{C}$ for $3 \mathrm{~h}$, and $\mathrm{KMnO}_{4}(5 \%, \mathrm{w} / \mathrm{v})$ at $100^{\circ} \mathrm{C}$ for $30 \mathrm{~min}$. The concentration of total mercury was measured using atomic absorption spectrophotometry with cold vapor (CVAAS) at a wavelength of $253.7 \mathrm{~nm}$ in a Thermo Electron spectrophotometer (6).

The detection limits for biological samples were $26.4 \mu \mathrm{g} / \mathrm{kg}$ dry for weight and $13.1 \mu \mathrm{g} / \mathrm{kg}$ for wet weight, respectively. The analytical quality
Colecta de muestras. Se capturaron Pelecanus occidentalis $(n=10)$ durante marzo de 2010 y julio de 2011 en la bahía de Cispatá, que incluyeron 6 especímenes jóvenes y 4 adultos, de acuerdo con sus variables morfométricas, como peso, largo del ala y del pico. Las aves fueron eutanizadas y transportadas inmediatamente al laboratorio para su disección con el fin de separar las plumas e hígado los cuales fueron etiquetadas y empacadas en bolsas de polietileno. Estos últimas fueron refrigerados hasta su análisis. El permiso para la captura y procesamiento de las aves fue autorizado por la autoridad ambiental local (Corporación Autónoma Regional de los Valles del Sinú y del San Jorge, CVS).

Análisis químico. Las muestras de plumas fueron lavadas con agua desionizada y acetona con el fin de la eliminación del metales libres, posteriormente fueron secadas a $60^{\circ} \mathrm{C}$ durante $48 \mathrm{~h}$ las muestras de hígado y plumas fueron digeridas con una mezcla de $\mathrm{H}_{2} \mathrm{SO}_{4}-\mathrm{HNO}_{3}(2: 1, \mathrm{v} / \mathrm{v})$ a $100-110^{\circ} \mathrm{C}$ por $3 \mathrm{~h}$, y $\mathrm{KMnO}_{4}(5 \%, \mathrm{p} / \mathrm{v})$ a $100^{\circ} \mathrm{C}$ por $30 \mathrm{~min}$. La concentración de mercurio total fue medida usando espectrofotometría de absorción atómica con vapor frío (CVAAS) a una longitud de onda de $253.7 \mathrm{~nm}$ en un espectrofotómetro Thermo Electron (6).

Los límites de detección para las muestras de plumas e hígado fueron de $26.4 \mu \mathrm{g} / \mathrm{kg}$ peso seco y $13.1 \mu \mathrm{g} / \mathrm{kg}$ peso húmedo, respectivamente. El control de calidad analítico fue realizado usando 
control was performed using certified reference material and doped samples. The concentrations of total mercury for the biological material (IAEA086; International Atomic Energy Agency) was $0.56 \pm 0.03 \mathrm{mg} / \mathrm{kg}(0.534-0.612 \mathrm{mg} / \mathrm{kg}$ certified value).

Statistical analysis. Mercury data analyzed are presented as mean \pm standard deviation. The results obtained were subjected to a normality test and Bartlett's test to verify their distribution. Since the data did not show a normal distribution, non-parametric statistics was used to make comparisons (Mant Whitney - Shapiro Wilk test) of the concentrations of metals found between juveniles and adults of the same and different species, all tests were performed at a significance level of $p<0.05$.

\section{RESULTS}

The concentrations of $\mathrm{T}-\mathrm{Hg}$ in liver and feathers are shown in figure 2 . The concentrations in feathers were in the range $0.31-9.17 \mathrm{mg} / \mathrm{kg}$ while in liver they were $0.63-6.29 \mathrm{mg} / \mathrm{kg}$.

Mercury concentrations in adult pelicans were higher than in young specimens and showed statistically significant differences $(Z=2.17$, $p \leq 0.05)$. The results for mercury in feathers were greater than those found in liver with averages of 4.06 and $3.02 \mathrm{mg} / \mathrm{kg}$, respectively. These values showed statistically significant differences $(p \leq 0.05)$.

\section{DISCUSSION}

Mercury in feathers can represent up to $93 \%$ of the accumulated body burden (7). High concentrations of mercury in feathers can be explained by the high affinity of this metal to keratin sulfhydryl groups (8). The concentrations of this metal in feathers above $5.0 \mathrm{mg} / \mathrm{kg}$ are associated with the reduction of reproduction (9), it is important to note that in this study the $\mathrm{Hg}$ levels found in both young and adult organisms evaluated are higher than this value and are above those reported in the literature for waterfowls. table 1 shows the comparison of the average concentrations found in this study and those of others conducted in different places of the world.

In the liver, total mercury concentrations can be explained by the ability of this organ to accumulate the metal as a result of the demethylase processes that take place in the same. The concentration of total mercury in birds is mainly due to the dietary habits of these organisms $(15,16)$; pelicans are material de referencia certificado y muestras dopadas. Las concentraciones de mercurio total para el material biológico (IAEA-086; Agencia De Energía Atómica Internacional) fue $0.56 \pm 0.03$ $\mathrm{mg} / \mathrm{kg}$ (0.534-0.612 mg/kg valor certificado).

Análisis estadístico. Los datos del mercurio analizados son presentados como la media \pm la desviación estándar. Los resultados obtenidos se sometieron a la prueba de normalidad y prueba de Bartlett, para verificar su distribución. Debido a que los datos no presentaron una distribución normal, se utilizó estadística no paramétrica para la realización de las comparaciones (prueba de Mant Whitney - Shapiro Wilk) de las concentraciones de metales halladas entre aves jóvenes y adultos de la misma y diferentes especies, todas las pruebas se realizaron a un nivel de significancia de $p<0.05$.

\section{RESULTADOS}

Las concentraciones de $\mathrm{T}-\mathrm{Hg}$ en hígado y plumas se muestran en la figura 2 . Las concentraciones en plumas estuvieron en un rango de 0.31-9.17 $\mathrm{mg} / \mathrm{kg}$, mientras que en hígado fueron de 0.63 $-6.29 \mathrm{mg} / \mathrm{kg}$.

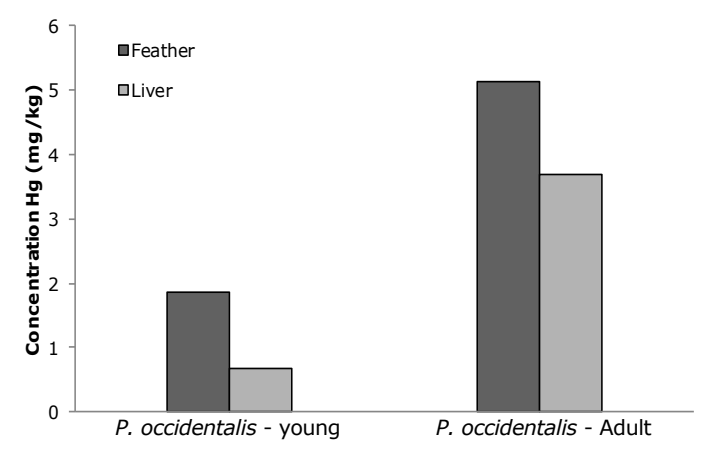

Figure 2. Total mercury levels in liver and feathers of $P$. Occidentalis in the Cispata Bay Colombia.

Las concentraciones de mercurio en pelicanos adultos fueron mayores que en los jóvenes y presentaron diferencias estadísticamente significativas $(Z=2.17, p \leq 0.05)$. Los resultados de mercurio en plumas fueron mayores a los hallados en hígado con promedios de 4.06 y 3.02 mg/kg, respectivamente. Estos valores mostraron diferencias estadísticamente significativas $(p \leq 0.05)$.

\section{DISCUSIÓN}

El mercurio en las plumas puede representar hasta el 93\% de la carga corporal acumulada (7). Las altas concentraciones de mercurio en plumas 
Table 1. Mercury Concentrations in the feathers and liver of waterfowls reported in the literature.

\begin{tabular}{|c|c|c|c|c|}
\hline Species & Location & Feathers & Liver & Ref \\
\hline Ardea alba & Nueva Jersey & $\begin{array}{c}2.61 \\
\pm 0.529\end{array}$ & - & (7) \\
\hline Larus michahellis & $\begin{array}{c}\text { Western } \\
\text { Mediterranean }\end{array}$ & $\begin{array}{l}2.43 \\
\pm 1.30\end{array}$ & - & $(10)$ \\
\hline Anas poecilorhyncha & $\begin{array}{l}\text { Mouth of the Yellow } \\
\text { River, China }\end{array}$ & - & $\begin{array}{c}0.200 \\
\pm 0.090\end{array}$ & (11) \\
\hline Ardea purpurea & & - & $\begin{array}{c}3.42 \\
\pm 0.54\end{array}$ & \\
\hline Phalacrocorax carbo & Lake Biwa, Japan & $\begin{array}{c}0.0028 \\
\pm 0.0027\end{array}$ & $\begin{array}{l}12 \\
\pm 9\end{array}$ & (12) \\
\hline \multirow[t]{2}{*}{ Cepphus Columba } & $\begin{array}{l}\text { Aleutian Islands, } \\
\text { Alaska }\end{array}$ & $\begin{array}{c}2.41 \\
\pm 0.297 *\end{array}$ & - & (13) \\
\hline & & $\begin{array}{c}3.30 \\
\pm 0.410 * *\end{array}$ & - & \\
\hline Anas platyrhynchos & $\begin{array}{l}\text { New Jersey } \\
\text { Meadowlands }\end{array}$ & $\begin{array}{c}0.258 \\
\pm 0.0418\end{array}$ & $\begin{array}{c}40.9 \\
\pm 6.72\end{array}$ & (14) \\
\hline Pelecanus occidentalis & $\begin{array}{l}\text { Cispata Bay, } \\
\text { Colombia }\end{array}$ & $\begin{array}{c}9.17 \\
\pm 1.43\end{array}$ & $\begin{array}{c}6.29 \\
\pm 1.67\end{array}$ & $\begin{array}{l}\text { This } \\
\text { study }\end{array}$ \\
\hline
\end{tabular}

* Birds not contaminated with crude oil.

** Birds contaminated with crude oil.

a piscivorous species mainly, in this context, their diet plays an important role in the accumulation of mercury (17).

Jakimska et al (18), found that the highest levels of mercury were recorded in the tissues of carnivorous marine birds evaluated in the study. Once the contaminant has been ingested it can be excreted directly or absorbed in the bloodstream; subsequently, the metal absorbed is carried and stored in white organs or stored in feathers (3). The content of mercury in the liver of young specimens was approximately five times lower than in adults. This fact can be explained by the limited ability of the biotransformation metabolism in young birds (6). Although mercury is a contaminant of interest in marine waters, the main source of mercury in the aquatic food chain comes from anthropogenic sources (7).

The bioavailability of mercury in sediments belonging to the study area was evidenced in the study developed by Paternina (19), who found that the exchangeable fraction of the metal reached $29 \%$, a fact that would explain the passage of the contaminant from fish to birds.

The results found in this study were higher than those reported by Houserova et al (15) for the liver of Phalacrocorax carbo $(3.40 \mathrm{mg} /$ $\mathrm{kg}$ ) and by Paez-Osuna et al (11) for Pelecanus occidentalis in muscle $(2.85 \mathrm{mg} / \mathrm{kg})$.

It is important to highlight that this study represents the first documented report on pueden ser explicadas por la gran afinidad de este metal hacia los grupos sulfhidrilo de la queratina (8). Las concentraciones de este metal en plumas por encima de $5.0 \mathrm{mg} / \mathrm{kg}$ están vinculadas a la reducción de la reproducción (9), es importante resaltar que para el presente estudio los niveles de $\mathrm{Hg}$ hallados tanto en los organismos jóvenes como adultos evaluados son superiores a este valor y se encuentran por encima de los registrados en la bibliografía para aves acuáticas. En la tabla 1 se muestra la comparación de las concentraciones promedio halladas en este estudio y las de otros realizados en diferentes lugares del mundo.

En hígado, las concentraciones de mercurio total pueden ser explicadas por la capacidad de este órgano para acumular el metal como consecuencia de los procesos de demetilación que son llevados en el mismo. La concentración de mercurio total en aves se debe principalmente a los hábitos alimenticios de estos organismos $(15,16)$; los pelicanos son una especie principalmente piscívora, en este contexto, su dieta juega un papel importante en la acumulación de mercurio (17).

Jakimska et al (18), encontraron que los niveles más altos de mercurio se registraron en los tejidos de las aves marinas carnívoras evaluadas en su estudio. Una vez ingerido el contaminante puede ser excretado directamente o absorbido en el torrente sanguíneo; subsecuentemente, el metal absorbido es llevado y almacenado en órganos blanco o secuestrado en las plumas (3). El contenido de mercurio en hígado de especímenes jóvenes fue aproximadamente 5 veces menor que en los adultos. Este hecho puede ser explicado por la limitada habilidad del metabolismo de biotransformación en las aves jóvenes (6). Aunque el mercurio es un contaminante de interés en las aguas marinas, la principal fuente de mercurio en la cadena alimentaria acuática proviene de fuentes antropogénicas (7).

La biodisponibilidad del mercurio en sedimentos pertenecientes a la zona de estudio fue evidenciada en el trabajo desarrollado por Paternina (19), quien encontró que la fracción intercambiable del metal alcanzó hasta el $29 \%$, hecho que explicaría el paso del contaminante de los peces a las aves.

Los resultados encontrados en este estudio fueron mayores a los reportados por Houserova et al (15) para hígado de Phalacrocorax carbo $(3.40 \mathrm{mg} / \mathrm{kg}$ ) y por Páez-Osuna et al (11) para Pelecanus occidentalis en musculo $(2.85 \mathrm{mg} / \mathrm{kg})$.

Es importante resaltar que este este estudio representa el primer reporte documentado acerca de la contaminación por mercurio en aves acuáticas del Caribe colombiano, brindando valiosa información 
the contamination by mercury in aquatic birds of the Colombian Caribbean, providing valuable information on the status of this type of organisms in the Cispata bay - Colombia. Mercury is the pollutant of greatest concern in the marine environment and this study verified the use of feathers as a non-invasive monitoring tool, as an alternative to the use of other tissues such as liver that can cause damage to the population of the organisms employed for environmental monitoring. This study confirms what has been found in many areas of Europe and in other continents, where birds have proven to be very useful $\mathrm{Hg}$ biomonitors, especially seabirds and waterfowls (20).

\section{Acknowledgements}

To the Universidad de Cordoba for its financial support and to the Research Group of Waters, Applied Chemistry and the Environment. sobre el estado de este tipo de organismos de la Bahía de Cispatá - Colombia. El mercurio es el contaminante de mayor preocupación en el ambiente marino y en este estudio se comprobó el uso de plumas como herramienta no invasiva de monitoreo, como alternativa al uso de otros tejidos como hígado que pueden causar daño a la población de los organismos empleados para el monitoreo ambiental. Con este estudio se confirma lo encontrado en muchas zonas de Europa, y también en otros continentes, donde las aves han demostrado ser muy útiles como biomonitores de $\mathrm{Hg}$, especialmente marinas y aves acuáticas (20).

\section{Agradecimientos}

A la Universidad de Córdoba por el apoyo financiero y al Grupo de investigación en Aguas Química Aplicada y Ambiental.

\section{REFERENCES}

1. Bond A, Diamond A. Mercury concentrations in seabird tissues from Machias Seal Island, New Brunswick, Canada. Sci Total Environ 2009; 407:4340-4347.

2. Zamani-Ahmadmahmood R, Esmaili A, Ghasempouri S, Savabieasfahani M. Mercury in wetland birds of Iran and Iraq: contrasting resident moorhen, Gallinula chloropus, and migratory Common Teal, Anas crecca, life strategies. B Environ Contam Tox 2009; 82:450-453.

3. Burger J. Gochfeld. Marine birds as sentinels of environmental pollution. Eco Health $2004 ; 1: 263-274$.

4. Burger J, Gochfeld M. Mercury and other metals in feathers of common eider (Somateria mollissima) and tufted puffin (Fratercula cirrhata) from the aleutian chain of Alaska. Arch Environ Contam Toxicol 2009; 56:596-606.

5. Corporación de los Valles del Sinú y San Jorge CVS. Plan de manejo integral - Zona de uso sostenible del sector estuarino de la bahía de Cispatá. Departamento de Córdoba, Colombia. Montería, Colombia: Corporación Nacional de Investigación y Fomento Forestal - CONIF; 2005.
6. Marrugo J, Benitez L, Olivero J. Distribution of mercury in several environmental Ccompartments in an aquatic ecosystem impacted by gold mining in northern Colombia. Arch Environ Contam Toxicol 2008; 55:305-316.

7. Burger J. Temporal trends (1989-2011) in levels of mercury and other heavy metals in feathers of fledgling great egrets nesting in Barnegat Bay. Environ Res 2013; 122:11-17.

8. Lucia M, Marc Andre J. Gontier K, Diot N, Veiga J, Davail S. Trace element concentrations (Mercury, Cadmium, Copper, Zinc, Lead, Aluminium, Nickel, Arsenic, and Selenium) in some aquatic birds of the southwest atlantic coast of France. Arch Environ Con Tox 2009. 58:844-53.

9. Burger J, Tsipoura N, Newhouse M, Jeitner C, Gochfeld M, Mizrahi D. Lead, mercury, cadmium, chromium, and arsenic levels in eggs, feathers, and tissues of Canada geese of the New Jersey Meadowlands. Environ Res 2011; 111:775-784.

10. Ramos R, Ramirez F, Jover LI. Trophodynamics of inorganic pollutants in a wide-range feeder: The relevance of dietary inputs and biomagnification in the Yellow-legged gull (Larus michahellis). Environ Pollut 2013; 172:235-242. 
11. Cui B, Zhang $\mathrm{O}$, Zhang $\mathrm{K}$, Liu $\mathrm{X}$, Zhang $\mathrm{H}$. Analyzing trophic transfer of heavy metals for food webs in the newly-formed wetlands of the Yellow River Delta, China. Environ Pollut 2011; 159:1297-1306.

12. Tanabe S, Nama D, Anan Y, Ikemoto T, Okabe $Y$, Kimb E, et al. Specific accumulation of 20 trace elements in great cormorants (Phalacrocorax carbo) from Japan. Environ Pollut 2005; 134:503-514.

13. Burger J, Gochfeld M, Sullivan K, Irons D. Mercury, arsenic, cadmium, chromium lead, and selenium in feathers of pigeon guillemots (Cepphus columba) from Prince William Sound and the Aleutian Islands of Alaska. Sci Total Environ 2007; 387:175-184.

14. Burger J, Tsipoura N, Newhouse M, Jeitner C, Gochfeld M, Mizrahi D. Lead, mercury, cadmium, chromium, and arsenic levels in eggs, feathers, and tissues of Canada geese of the New Jersey Meadowlands. Environ Res 2011; 111:775-784.

15. Houserova P, Kuban V, Kracmar S, Sitko J. Total mercury and mercury species in birds and fish in an aquatic ecosystem in the Czech Republic. Environ Pollut 2007; 145:185-194.
16. Ruelas J, Paez F, Arvizu M. Mercury Distribution in Selected Tissues of Migratory and Resident Avifauna from Altata-Ensenada del Pabellón Lagoon, Southeast Gulf of California. Bull Environ Contam Toxicol 2007; 78:39-43.

17. Páez-Osuna F, Ruelas-Inzunza J, HernándezOsuna J. Organic and total mercury in muscle tissue of five aquatic birds with different feeding habits from the SE Gulf of California, Mexico. Chemosphere 2009; 76:415-418.

18. Jakimska A, Konieczka P, Skora K, Namiesnik J. Bioaccumulation of metals in tissues of marine animals, part II: metal concentrations in animal tissues. Environ Stud 2011; 20:1127-1146.

19. Paternina R. Evaluación de la contaminación por metales pesados en la Ciénaga la Soledad y Bahía de Cispatá, cuenca del Bajo Sinú, departamento de Córdoba [Tesis de Maestría]. Montería: Universidad de Córdoba; 2011.

20. Stankovic S, Kalaba P, Stankovic A. Biota as toxic metal indicators. Environ Chem Lett. 2013 jun. [Epub ahead of print]; 2(103). Disponible en: http://link.springer.com/ article/10.1007/s10311-013-0430-6. 